\title{
LOUIS GALLAVARDIN
}

On December 2, 1957, at Lyons, Louis Gallavardin, aged 83, died peacefully in his sleep after a brief illness. A great pioneer in cardiology has departed, and as one who had enjoyed his friendship for over thirty years it is my sad privilege to give some account of him.

Born in Lyons in 1875, Gallavardin was trained in the Lyons Medical School, becoming Interne in 1895, and Médecin des Hôpitaux de Lyon in 1902, at the early age of 27 . As an interne he was a contemporary of Alexis Carrel with whom he remained a lifelong friend. Of his teachers, Tripier influenced him most and he often spoke with admiration of Bouveret.

From 1898 to 1945 , Gallavardin published 360 papers covering the whole field of cardiovascular disease with the exception of congenital malformations which except for aortic stenosis never interested him much. Written at a time when cardiology was advancing with rapid strides and attracting many new disciples to its ranks, these papers soon established Gallavardin's reputation as a leader of cardiology in Europe.

A list of his publications shows that up to 1910 he was still concerned with general medicine, though there was an early paper with Josserand (1901) on heart failure in young subjects due to primary myocarditis; this gave the first clear clinical and pathological account of a rare form of heart disease which later received much attention under the name of isolated or Fiedler's myocarditis. After 1910 his interests became centred on cardiovascular disease, and he must have been one of the first physicians in Europe to devote himself to the practice of cardiology.

At the start of the century, early models of the Riva-Rocci type of sphygmomanometer were coming into regular use, in spite of some opposition from physicians who still held the erudite finger to be the best pressure gauge. At first only the systolic pressure could be recorded, but with the advent of the auscultatory method (Korotkoff, 1905) and the Pachon oscillometer (1909), it became possible to estimate the diastolic pressure also. Gallavardin was an early worker in this field and his book La Tension artérielle en Clinique, first published in 1910 with the second enlarged edition in 1920, was for long the standard work on the measurement of blood pressure; its remarkably complete bibliography makes it still a valuable source of reference.

He was by nature and choice a clinician rather than a laboratory worker, but from the first he appreciated the great importance of electrocardiography, acquiring one of the original Cambridge cardiographs which was still in use when I visited him in 1926. He was a great admirer of Mackenzie whose work stimulated his interest in the arrhythmias, and from 1912 onwards Gallavardin applied himself to their methodical investigation, using a paper camera with the Cambridge electrocardiograph for this purpose. He acquired a vast collection of records of every sort of abnormal rhythm, many of which were reproduced in his papers. It was in Lyons that Bouveret wrote his classic description of paroxysmal tachycardia (1889) and it was natural for Gallavardin to interest himself in this form of arrhythmia, about which he made many valuable contributions, including statistics of 177 cases in 1930. He made a particular study of ventricular tachycardia, identifying a relatively benign form with frequent ventricular extrasystoles. Many of his observations were embodied in the book published in 1932 by Froment, who gave us some account of the work of the Lyons School in the British Heart Journal of 1953.

Gallavardin was interested in aortic stenosis and was the first to emphasize the frequency of a type that was not rheumatic "qui se caractérise par sa tendance particulière à réaliser le rétrécissement aortique pur et que cette cause doit être recherchée en dehors des atteintes rhumatismales franches ou frustes." He published a series of papers $(1909,1921$, and 1936) and in the last described 50 such patients: he emphasized the frequent occurrence of effort syncope in this disease. Though this type is now generally regarded as congenital, the accuracy of his general picture has not been questioned.

In 1921, Gallavardin described paroxysmal pulmonary œdema in mitral stenosis, and in 1934 published his notable paper Le rétrécissement mitral edemateux in which he clearly delineated a form of mitral disease that was then little known but is now recognized as the form that above all others demands surgical relief. 
He made a lifelong study of angina pectoris of which he acquired a vast experience in practice, and his modest treatise, Les Angines de Poitrine (1925), contains one of the best clinical descriptions of the anginal syndrome ever written. He was far too logical a thinker ever to be lured from the narrow path of proven facts by Allbutt's plausible aortic hypothesis, and never doubted that coronary disease was the most important cause of anginal pain.

Gallavardin's published work was not his main achievement. Almost single-handed, and at a time when Vaquez's clinic dominated cardiology in France and indeed in Europe, he founded a new and independent school of cardiology in Lyons. From the start this school has been served by its own men, trained in Lyons, men such as Gravier, Veil, and Froment, and including today Leon Gallavardin and Jean Gravier, who have followed in their fathers' footsteps.

Gallavardin was a great clinician and a master of observation at the bedside where nothing seemed to escape him, and I still retain a vivid recollection of his ward rounds at the ancient HôtelDieu Hospital: first a penetrating interrogation of the patient, next a rapid yet meticulous examination, then a lucid but concise summing up, and finally the dictation of a brief but most illuminating summary of his conclusions for the notes. In clarity of thought and in ability to focus his mind straight on to the kernel of any problem, he reminded one of Lewis. His whole working life was spent in Lyons and in his later years he showed little inclination to leave his home town. He became President of the Société Française de Cardiologie in 1946, but I believe that he needed firm persuasion from Laubry to accept this honour which involved frequent sojourns in Paris.

He was much interested in paintings, miniatures, Persian art, and fine editions, and yet he was a man of simple habits, neat and punctilious in dress, precise and almost brusque in speech, quick but unhurried at work. I am sure that he would wish no better description of himself than that which he gave of Gravier: "le fidèle représentant du médecin hospitalier lyonnais" and so let us think of him with honour and affection.

D. EVAN BEDFORD

\section{SELECTED BibliograPHY \\ General}

1901. (With Josserand, E.) De l'asystolie progressive des jeunes sujets par myocardite subaigue primitive. Arch. gén. Méd., 188, 513 and 684.

1910. La Tension artérielle en Clinique, sa Mesure, sa Valeur séméiologique. Paris. 2nd edition in 1920.

1921. Symptômes et diagnostic de l'infarctus du myocarde. J. Méd. Lyon, 2, 911.

1925. Les Angines de Poitrine. Paris.

Aortic Stenosis and Syncope on Effort

1909. Du rétrécissement aortique non-rhumatismal des jeunes sujets et de son analogie avec le rétrécissement mitral de Duroziez. Lyon méd., 112, 189.

1921. Le rétrécissement pur non-rhumatismal des jeunes sujets. Presse méd., 29, 224. Also, in 1936. J. Méd.Lyon, $17,593$.

1933. Les syncopes d'effort. Lyon méd., 151, 217.

\section{Paroxysmal Tachycardia}

1912. Tachycardie paroxystique angineuse. Lyon méd., 118, 320.

1922. Extra-systolie ventriculaire à paroxysmes tachycardiques prolongés. Arch. Mal. Coeur, 15, 298.

1930. (With R. Froment.) La tachycardie paroxystique: maladie de Bouveret, d'après une statistique de 177 observations. J. Méd. Lyon, 11, 617.

1932. R. Froment. Les Tachycardies paroxystiques ventriculaires. Masson et Cie, Paris.

Mitral Stenosis and Pulmonary Edema

1921. De l'œdème pulmonaire aigu dans les cardiopathies valvulaires endocardiques en dehors de la gravidité; insuffisance ventriculaire gauche et insuffisance auriculaire gauche. Arch. Mal. Cour, 14, 262.

1934. Le rétrécissement mitral œdemateux. J. Méd. Lyon, 15, 609. 